\title{
Prevalence of colonisation with third generation cephalosporin-resistant enterobacteriacae (3GCREB) on admission - a cross-sectional study in 6 university hospitals
}

AM Rohde ${ }^{1 *}$, J Zweigner ${ }^{2}$, M Wiese-Posselt ${ }^{1}$, A Hamprecht ${ }^{2}$, W Kern ${ }^{3}$, P Gastmeier ${ }^{1}$, H Seifert ${ }^{2}$, DZIF - ATHOS study group

From 3rd International Conference on Prevention and Infection Control (ICPIC 2015) Geneva, Switzerland. 16-19 June 2015

\section{Introduction}

This admission prevalence survey is part of the multicenter study ATHOS (antibiotic therapy optimisation study). ATHOS aims at collecting prevalence and incidence data for nosocomial carriage of multi-drug resistant organisms (MDROs) and to intervene in the inpatient and outpatient setting.

\section{Objectives}

The aim of this admission prevalence survey was to assess the rectal carriage of third generation cephalosporin-resistant enterobacteria (3GCREB) in patients on hospital admission and to perform risk factor analyses for 3GCREB carriage.

\section{Methods}

In 2014, we recruited adult patients within $72 \mathrm{~h}$ of admission to non-intensive care units in six German university hospitals. We obtained rectal swabs that were screened for 3GCREB. Each patient was asked to answer a short questionnaire on potential risk factors for colonisation with MDROs. Univariable and multivariable risk factor analyses were performed on preliminary data to identify those factors that were associated with 3 GCREB prevalence.

\section{Results}

Of the 4372 patients included, 423 patients were 3GCREB carriers (admission prevalence of 9.7\%). Most isolates were Escherichia coli (76.8\%). Surprisingly,
$41.9 \%$ of all 3GCREB isolates were additionally resistant to fluoroquinolones. Only two patients $(<0.1 \%)$ were colonised with carbapenemase-producing enterobacteria. Multivariable analysis associated the following risk factors with 3GCREB colonisation: centre, previous MDRO colonisation $(\mathrm{OR}=2.16, \mathrm{p}<0.001)$, antibiotic use $(\mathrm{OR}=2.08, \mathrm{p}<0.001)$, travel abroad $(\mathrm{OR}=1.26, \mathrm{p}=0.033)$ and management of gastroesophageal reflux disease (GERD) $(\mathrm{OR}=1.1, \mathrm{p}=0.047)$.

\section{Conclusion}

To our knowledge, this is one of the largest admission prevalence surveys of 3GCREB in Germany. Interestingly, medical management of GERD and the specific centres to which the patients where admitted proved to be additional risk factors for 3GCREB colonisation on hospital admission. Whether information present on admission will be useful to improve prediction of nosocomial colonisation and infection as well as target infection control measures and therapy needs to be determined.

\section{Disclosure of interest}

None declared.

\section{Authors' details}

${ }^{1}$ Charité, Berlin, Germany. ${ }^{2}$ University Hospital Cologne, Cologne, Germany. ${ }^{3}$ University Hospital Freiburg, Freiburg, Germany.

Published: 16 June 2015 


\section{doi:10.1186/2047-2994-4-S1-043}

Cite this article as: Rohde et al:: Prevalence of colonisation with third generation cephalosporin-resistant enterobacteriacae (3GCREB) on

admission - a cross-sectional study in 6 university hospitals.

Antimicrobial Resistance and Infection Control 2015 4(Suppl 1):043.

Submit your next manuscript to BioMed Central and take full advantage of:

- Convenient online submission

- Thorough peer review

- No space constraints or color figure charges

- Immediate publication on acceptance

- Inclusion in PubMed, CAS, Scopus and Google Scholar

- Research which is freely available for redistribution

Submit your manuscript at www.biomedcentral.com/submit
C Biomed Central 